\title{
Effect of Different Resistance Intensities on Changes of Inflammatory and Muscle Damage Markers in Man
}

\author{
Byung Roh Kim', Jin Hong Kim² \\ 'Physical Education of Changwon University, Changwon, Republic of Korea \\ ${ }^{2}$ Sports Health Care of Inje University, Gimhae, Republic of Korea
}

Received: July 5, 2018

Accepted: August 20, 2018

Published online: October 31, 2018

Keywords:

CK

C-reactive protein

IL-6

$\mathrm{LDH}$

Resistance exercise intensity
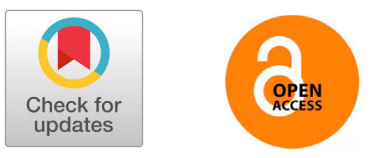

\section{ABSTRACT}

OBJECTIVES This study was to investigate the change of inflammatory markers and fatigue substance of muscle damage on different resistance exercise intensities.

METHODS The subjects were 7 students (age, $21.0 \pm 1.56$ ) in physical education department C University in Gyeongnam. The same amount of exercise was applied to each subject by low and high intensity resistance exercise. Inflammatory and muscle damage markers were based on IL-6, CRP, Myoglobin, CK and LDH. The changes of inflammatory and muscle damage markers on different exercise intensities were measured pre and immediately post exercise and during recovery periods. Blood was collected at each time and analyzed.

RESULTS The IL-6 level was significantly lower (0.526) after 24 hours than before exercise in the high intensity exercise. Regardless of the difference in exercise intensities, the change was significantly higher( $p$ $<.001$ ) after exercise than immediately post exercise and recovery periods( 3 hours, 24 hours later). CRP was lower at 3 hours post recovery than at pre - exercise, but there was no significant difference between the intensities of resistance and the time of pre and post exercise. Myoglobin was found to be low $(3.19 \mathrm{ng} / \mathrm{ml})$ at 24 hours post exercise in high intensity exercise, but it was not related different in resistance intensities and was influenced by time $(p<.01)$. CK was not related to exercise intensities. Regardless of the high or low intensities of exercise, there was a significant change after exercise $(p<.01)$. LDH was not related to the difference in exercise intensity. After 24 hours of both intensity resistance exercise, LDH was lower than before exercise, but the time-period change was high $(p<.001)$.

CONCLUSIONS Inflammatory and muscle damage markers were not related to exercise intensity. Regardless of the intensity of exercise, Without CRP were changed at the time periods.

๑ The Asian Society of Kinesiology and the Korean Academy of Kinesiology

서론

저항운동은 근력과 근지지력, 근비대 등 근관절에 가해 지는 저항에 견딜 수 있는 무게와 반복횟수 그리고 시간을 기준으로 강도와 운동량 등을 평가한다. 따라서 강도와 반

*Correspondence: Jin Hong Kim, Sports Health Care, In Je University, 197 Inje -Ro Gimhae, Gyungnam , Korea.

E-mail: smedizin@Inje.ac.kr
복횟수 그리고 운동량에 따라 근비대, 근지구력, 근파워에 영향을 미치게 된다. 또한 저항에 동원된 근관절은 근력 향상에 긍정적 작용과 함께 잘못된 운동방법에 따라 부정 적인 경우도 발생 된다. 저항운동에 염증유발의 부정적인 영향은 지나친 무게의 반복에 따른 과부하 또는 저항운동 에 익숙하지 않은 것에 그 원인을 찾을 수 있다. 그러나 저 항운동에서 염증유발은 정도의 차이는 있을 수 있으나 근 력운동에 피할 수 없는 것 또한 일반적인 현상이다[14,39]. 
운동중에 급성으로 발생한 염증과 만성적으로 지속되는 통증 모두 바이러스 원인 보다는 조직의 손상에 따른 염 증에 기인한 것으로 보고 있다. 지나친 부하의 근력운동 뿐만 아니라 오래 지속되는 유산소운동에 이르기까지 염 증 유발 반응이 운동학 연구에서 보고되었다[44,45]. 물론 바이러스 감염에 따른 인체의 방어적 기능 작용에 따른 염증반응 상승과 저항 운동시 발생하는 근조직손상에 따 른 염증유발의 지표는 다르지만 혈중 Interleukin-6(IL-6), C-reactive protein(CRP), Creatine kinase(CK) 농도가 염증 정도의 근거와 기준이 된다[3,5].

저항운동이 인체 부위의 표적이 되는 근관절에 지속적 으로 반복되는 작용에 의한 근 손상이 일반적 현상이지 만, 운동경험 여부에 따라 그 차이는 달라진다는 것 또한 일반적 견해이다. 근육에 부가되는 자극의 반복적 작용 은 근 손상뿐만 아니라 피로를 유발하여 근력의 저하와 운동지속시간에 영향을 미칠 수 있다. 저항운동과차이는 있으나 유산소운동의 중장거리 달리기 또는 마라톤과 같 은 고강도 운동 후 24 시간이 지난 뒤에도 $\mathrm{CRP}$ 증가를 언 급하였다[32]. 즉 지속적인 반복 스트레스를 가하는 저항 운동과 유사한 결과를 낳게 된다[50]는 역도선수 훈련 중 경험한 CRP 증가도 특별한 현상은 아니었다. 이렇게 염 증의 높고 낮음은 $\mathrm{CRP}$ 의 전구물체인 Interleukin-6와 CRP 의 농도에 따라 판단된다. 앞에 언급한 바와 같이 고강도 운동 후 발생되는 혈중 $\mathrm{CRP}$ 증가는 과도한 산화적 스트 레스, 산성증, 열 등에 의해 근육 손상에 따른 염증지표의 충분한 근거다 $[6,18,30,32,49]$. 또한 근육 손상의 범위와 높 은 염증반응 발생 가능성은 결국 저항성 운동 강도의 초 점이 된다. 그 근거로 운동형태, 강도, 지속시간에 따른 염 증반응 차이를 들 수 있다[39]. 또 다른 예로 종양괴사인자 TNF- $\alpha$, IL-6의 증가를 고강도 플라이오메트릭스 운동 후 경험한 것에 추측을 가능케 한다 $[6,7,19,28]$.

저항 및 유산소성 운동에 의해 나타나는 염증지표 외 에 근손상과 피로의 근거가 되는 $\mathrm{LDH}$ 의 혈중 농도는 종 양지표로 활용되기도 하지만 운동강도의 차이는 물론 운 동 경험자와 비경험자의 판별기준이 된다. 즉 유·무산소 운동에 관계없이 강도의 차이는 곧 혈중 젖산 농도에 영 향을 미치게 되고, 피로물질의 증가는 운동수행 지속시 간에 영향을 준다. 또한 운동경험자는 비경험자에 비하 여 피로물질에 대한 저항 능력 높아 동일한 강도의 운동 수행에 있어 운동 비경험자 보다 더 오래 지속할 수 있는 근거다. 운동 강도의 측면에서도 높은 강도는 운동수행의
시간을 단축하게 하고 낮은 강도는 운동 수행시간을 늘릴 수 있는 것과 같은 맥락이다[13,25].

IL-6는 염증지표의 기준이 되기도 하지만 인슐린의 민 감도에 영향을 미친다. 운동수행에 따른 에너지 대사에 근육의 수축과 이완 등 반복적인 작용은 염증유발의 정도 가 유산소성 운동보다 더 높다. 따라서 건강한 성인 남성 을 대상으로 $1 \mathrm{RM}$ 의 $50 \%$ 강도로 10 주간 트레이닝 후 IL-6 의 농도가 트레이닝 전보다 $44 \%$ 나 상승한 것에 의미가 있 다[16]. 따라서 유산소운동의 강도와 운동지속시간 간의 $\mathrm{LDH}$ 농도의 높고 낮음이 저항운동의 강도에 따른 염증 지표의 혈중 농도와 같은 맥락에서 비교되는 것도 일리가 있다. 또한 운동강도의 차이에 따른 염증과 피로현상에 관한 매우 민감한 지표의 보고에도 의미를 둘 수 있다[43]. 예로 면역세포의 기능과 생존 그리고 성장을 돕는 단백질 형태로 분비되는 사이토카인을 들 수 있다[1]. 이러한 사 이토카인은 호중구와 대식세포는 물론 섬유아세포와 혈 관 내피세포 그리고 운동으로 손상된 근육세포뿐만 아니 라 여러 종류의 다양한 세포에서도 분비된다[9].

이러한 염증성 사이토카인은 산화적 스트레스의 병리 적인 현상으로 그 종류는 TNF- $\alpha$ 와 본 연구의 관심 대상인 IL-6, CRP 등을 들 수 있다. 특히 IL-6, CRP는 운동 강도에 민감하게 반응을 하는 사이토카인이다 $[1,2,10,40]$. 한편 급 성이나 만성 트레이닝으로 인한 근육 손상시 혈중으로 방 출되는 $\mathrm{CK}$ 도 근육조직 손상정도의 지표로 운동에 따른 염증 발생을 보다 더 자세하게 알 수 있다[5]. 저항성 운동 에 따른 구조적 손상이 근육은 물론 결체조직에 나타나면 염증반응이 일어나게 되는바, 염증이 통증을 동반한 현상 이 계속되면 지연성 근육통증을 낳게 된다[17]. 그래서 과 도한 트레이닝을 삼가고 적합한 저항강도를 설정하여 운 동으로 나타날수 있는 부정적인 요소의 최소화가 반드시 선행되어야 한다. 그래서 다양한 강도의 운동을 적용하여 그에 대한 반응의 정도를 면밀하게 관찰하는 것이 필요하 다. 이렇게 운동의 부작용을 피하면서 효과를 극대화 하 는 것이 운동학의 과제다.

경기를 앞둔 선수는 필연적으로 운동의 부작용을 동반 하는 훈련을 피할 수 없다 하더라도 건강관리를 위한 체 력 향상과 유지 목적의 일반인들은 반드시 고려해야 할 부분이다. 지나친 과부하를 피하고 적절한 강도의 선정 을 위하여 수많은 연구들이 반복되었으나 논란은 반복되 고 있다. 또한 저항운동 강도의 차이에 따른 트레이닝 후 IL-6의 변화의 차이가 없었다는 것과 염증반응의 변화에 
나타나는 일반적 현상이 분명치 않은 결론[52]도 연구의 지속성에 영향을 미친다. 운동은 약물에 나타나는 부작용 에 비하여 높고 낮음을 가늠할 수 있는 기준이 명확치 않 아 특정한 신체적 손상을 유발하거나 과부하로 인한 위험 성을 간과하지 않는 한 긍정적인 효과가 크기 때문에 부 정적인 요소는 종종 관심을 벗어나게 된다. 그래서 지금 까지도 순환계에 영향의 유산소적 운동과 근골격에 더 많 은 자극이 작용하는 저항성운동에 대한 최적의 강도를 찾 아내는 것이 관심의 대상이었다. 저항운동의 강도 설정에 가장 일반적으로 활용되는 $1 \mathrm{RM}$ 기준에 특별한 비판은 아 직까지 나타나고 있지 않다. 다만 대상자에 설정된 강도 가 운동의 목적에 맞고 더 효과적인가에 대한 견해는 연 구자들에 따라 다르게 나타나고 있다[13,14].

체력에 따른 운동강도의 중요성을 논하면 전체 운동량 에 대한 견해가 다른 의견이 나타나고, 운동의 시간과 반 복횟수에 따른 차이점 등이 늘 등장했다. 그래서 본 연구 에서는 일반적인 건강관리 대상자에게 저항운동의 강도 의 차이에 따른 근손상의 염증반응이 운동 전후 차이를 확인해 볼 필요성을 갖게 되었다. 뿐만 아니라 운동강도 에 따른 근손상과 염증지표 농도 및 근손상과 피로의 변 화과정 추이를 통해 저항운동에 참여하는 일반인의 운동 효과와 부작용에 대한 정보를 제공하여 저항운동을 바르 게 이해하도록 하는 것이 목적이다

\section{연구 방법}

\section{연구대상}

본 연구의 대상은 의학적인 질환이 없고 $2\lceil 3$ 회/주 정 규 운동프로그램에 참여하는 G도 C대학교 체육학과 일 반학생 7명으로 하였다. 체육학과 일반학생을 피험자로 선정한 이유는 예비실험에서 일반인 대상으로 실행한 결 과 1-RM 측정의 곤란함과 사전 저항운동 경험이 없는 상 태로 실험에 참여할 경우 국소적인 피로현상의 언급과 저 항강도의 차이에 따른 동일운 운동량수행의 어려움이 있 었기 때문이다.

그리고 동일 피검자를 대상으로 반복 측정한 실험방법 을 선택하여 대조군을 둔 실험에서 발생될 수 있는 동질 성 문제를 최소화하였다. 저항운동 실험에 참여하기 전 대상자는 실험의 목적과 진행절차, 실험 중 발생 할 수 있 는 안전에 관한 주의사항 등을 설명하였다. 또한 대상자 가 실험에 참여 의사를 스스로 결정했어도 실험 당일 또

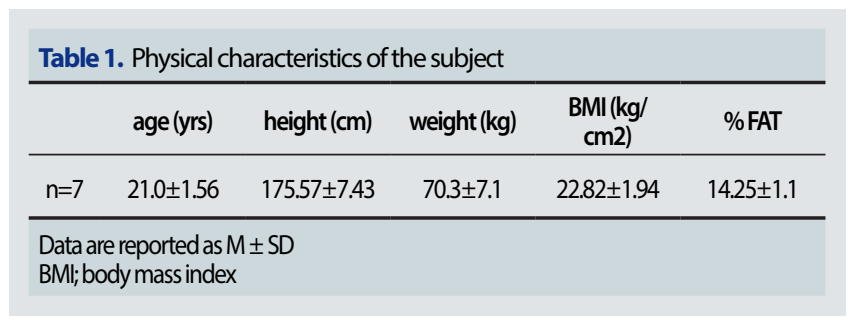

Table 2. Resistance exercise test item according to resistance strength

\begin{tabular}{cccc}
\hline Exercise testitems & $\begin{array}{c}\text { Intensity } \\
\text { level }\end{array}$ & Repetitions & RepeatSet \\
\hline $\begin{array}{c}\text { Seated bench press, Barbell } \\
\text { shoulder press, Pull lown, back } \\
\text { extension, Sit up, Leg curl, Leg } \\
\text { press, Calf raise }\end{array}$ & Low & 11 12/set & 3 sets \\
\hline
\end{tabular}

는 사전에 실험참여 철회는 자유롭게 수용하였다. 실험에 서 발생할 수 있는 내용은 사전 동의서에 포함하였고, 동 의서 사인여부는 대상자 본인이 결정하였다. 실험기간 중 저항운동 실험에 영향을 미칠 수 있는 카페인, 흡연, 특별 한 식이, 과격한 신체활동 등은 금하도록 하였다. 피험자 의 신체적 특성은 < Table $1>$ 과 같다.

\section{실험절차}

실험에 참여한 대상자는 적응운동, 예비실험, 1 차 실험 과 2 차 실험으로 구분하여 실시하였다. 저항 운동을 10$\mathrm{RM} / \mathrm{set}$ 강도로 3 세트씩 2 일간 수행하여 종목에 따른 저 항에 적응할 수 있도록 사전연습을 실행하였다<Table 2>.

사전 적응운동 연습은 전문강사를 통하여 저항운동시 각 관절의 정지각도 및 시간, 바의 위치, 안전 주의사항 등 을 철저히 지도하여 동작을 일정하고 동일하게 수행토록 하였다. 적응운동 2 주후에 예비실험, 1 차, 2 차 실험은 저 항성 운동에 따른 지연성 근육 통증과 염증반응의 영향을 통제하기 위하여 2주의 간격을 두어 실행하였다. 예비실 험은 피험자 개인별 1-RM을 측정에 초점을 두어 진행하 였으며, 방법은 간접추정식 $[1-\mathrm{RM}=$ 들어 올린 무게 + (들 어 올린 무게 $\times$ 들어 올린 횟수 $\times 0.025)]$ 을 적용하여 정하 였다[20,24]. 운동강도에 따른 염증반응 연구의 대부분은 수행 운동량이 동일하지 않아 결과의 일반화에 다소 신뢰 성의 문제가 있었다. 그래서 본 연구의 실험은 동일한 운 동량 수행을 위하여 예비실험에서 정한 $1 \mathrm{RM}$ 을 기준으로 4 5회 반복할 수 있는 고강도와 11 12회 반복수행할 수 있는 저강도 부하량을 고려하여 설정하였다. 
이렇게 선행연구를 참고로 운동강도의 차이에 따른 실 험 대상자에 게 동일한 운동량을 수행하도록 하기 위하여 본 연구의 1 2차 실험에 총운동량(세트 $\times \mathrm{RM} \times$ 부하량) 을 동일하게 적용하였다[8,21,52]. 앞에 언급한 바와 같이 실험대상자에 영향을 미칠 수 있는 요소를 차단하기 위 하여 2 주간격의 충분한 휴식기간을 두고 실행한 1 차와 2 차 실험도 교차방법으로 운동강도 혼합 조건을 동일하게 하였다.

본 연구의 실험대상자에게 부여된 운동시간은 1 시간 10 분으로 준비운동 10 분, 저항운동 50 분 정리운동 10 분으 로 구성하였다. 준비운동은 체조와 스트레칭 후 $1-\mathrm{RM}$ 의 $30 \%$ 에서 약 12 회를 2세트 수행하도록 하였다[52]. 본운동 의 저항운동은 강도의 차이와 근력, 지구력 등을 고려하 여, 고강도 저항운동시에는 세트간 휴식을 3 분으로 하였 고, 저강도 저항운동시에는 세트간 휴식을 2 분으로 하였 다 $[8,21$,$] . 물론 운동시 각 관절의 정확한 정지시간도 원심$ 성 수축시 2초, 구심성 수축엔 1 2초 유지하게 하였다[29]. 저항운동 종목별 반복 실행 횟수와 세트의 빈도 증가에 따른 대상자의 피로감 증가는 실험중단 시점 도달 의미 로 사전에 충분히 기타 고려사항으로 주지하고, 또한 실 험 중 구두로 독려하였다.

\section{채혈 및 분석항목}

영실험에 참여한 대상자는 저강도 및 고강도 저항운동 시 각각 4 회 채혈에 임하였다. 1 차 안정시는 실험당일 12 시간 공복 상태인 오전 9시경 좌측 상완정맥에서 약 $10 \mathrm{ml}$ 를 채혈하였으며, 2 차는 저항운동 직후, 3 차는 운동후 3 시 간 뒤에 그리고 4 차는 24 시간 후 동일한 방법의 채혈 후 혈 장을 수집하기 위하여 무처리 튜브에 30 분간 응고, 10 분 간 3000rpm으로 원심분리 냉동 처리하여 $\mathrm{N}$ 제약회사 분 석실에 의뢰하여 분석하였다. 채취한 저항운동 대상자의 혈액분석을 통하여 얻은 혈중 염증변인, 근손상, 피로물 질 항목은 IL-6, CRP, CK, Myoglobin 및 $\mathrm{LDH}$ 로 한정하였 다. IL-6는 효소면역분석법(enzyme-linked immunosorbent assay)으로 versamax(USA)으로 그리고 CRP, CK, Myoglobin 및 $\mathrm{LDH}$ 는 자동 생화학 분석기(Hitachi 7080, Japan)를 통해 분석되었다.

\section{자료처리방법}

본 연구는 통계처리 프로그램 SAS(ver. 9.0)을 이용하여 분석하였다. 본 연구의 결과는 평균 $(\mathrm{M}) \pm$ 표준편차(SD)로
제시하였다. 저항성 운동강도의 차이에 따른 측정시점 간 변인의 비교를 위하여 반복측정에 의한 이원변량분석 (two-way ANOVA by repeatision)을 시행하였다. 모든 통계 분석에서 P 값이 0.05 미만인 경우, 통계적으로 유의한 것 으로 판정하였다.

\section{결과}

\section{인터루킨-6(IL-6) 변화}

IL-6 농도 변화는 저강도와 고강도 모두 운동전에 비해 운동 후 높게 나타났다. 또한 저강도 운동전에 비해 운동 후 3 시간, 운동 후 24 시간도 높게 나타났다. 고강도 운동 도 운동전에 비해 운동 후 3 시간에 높게 나타났다가 운동 후 24 시간에는 낮아졌다. 변량분석 결과 운동강도에 따 른 유의차는 나타나지 않았고, 측정시점별 유의차가 나 타났다(p<.001). 상호작용효과는 나타나지 않았다<Table 3 , Figure $1>$.

\section{C-반응성 단백질(CRP) 변화}

$\mathrm{CRP}$ 농도 변화는 저강도와 고강도 모두 운동전에 비 해 운동 후, 운동 후 3 시간과 24시간에서 증가하는 양상을 보였다. 변량분석 결과 운동강도와 측정시점별 유의차가 없는 것으로 나타났다. 상호작용효과도 나타나지 않았다 $<$ Table 3, Figure 2>.

\section{미오글로빈(myoglobin) 변화}

미오글로빈 농도 변화는 저강도와 고강도 모두 운동전 에 비해 운동 후, 운동 후 3 시간에 증가하였다. 또한 저강 도 운동전에 비해 운동 후 24 시간에도 증가하였다. 하지 만 운동 후 3 시간에 비해 운동 후 24 시간에는 감소하는 것 으로 나타났다. 고강도 운동에서 운동전에 비해 운동 후 3 시간에 높게 나타났다가 운동 후 24시간에는 낮게 나타났 다. 변량분석 결과 운동강도에 따른 유의차는 나타나지 않았지만 측정시점별 유의차가 나타났다 $(\mathrm{p}<.01)$. 상호작 용효과는 나타나지 않았다<Table 3, Figure 3>.

\section{크레아틴 키나아제(CK) 변화}

$\mathrm{CK}$ 농도 변화는 저강도와 고강도 모두 운동전에 비해 운동 직후, 운동 후 3 시간과 24 시간에 증가하였다. 또한 운 동 후 3 시간에 비해 운동 후 24 시간에는 감소하는 것으로 나타났다. 변량분석 결과 운동강도에 따른 유의차는 나타 
Table 3. Change of IL-6, CRP, myoglobin, CK, LDH (M \pm SD)

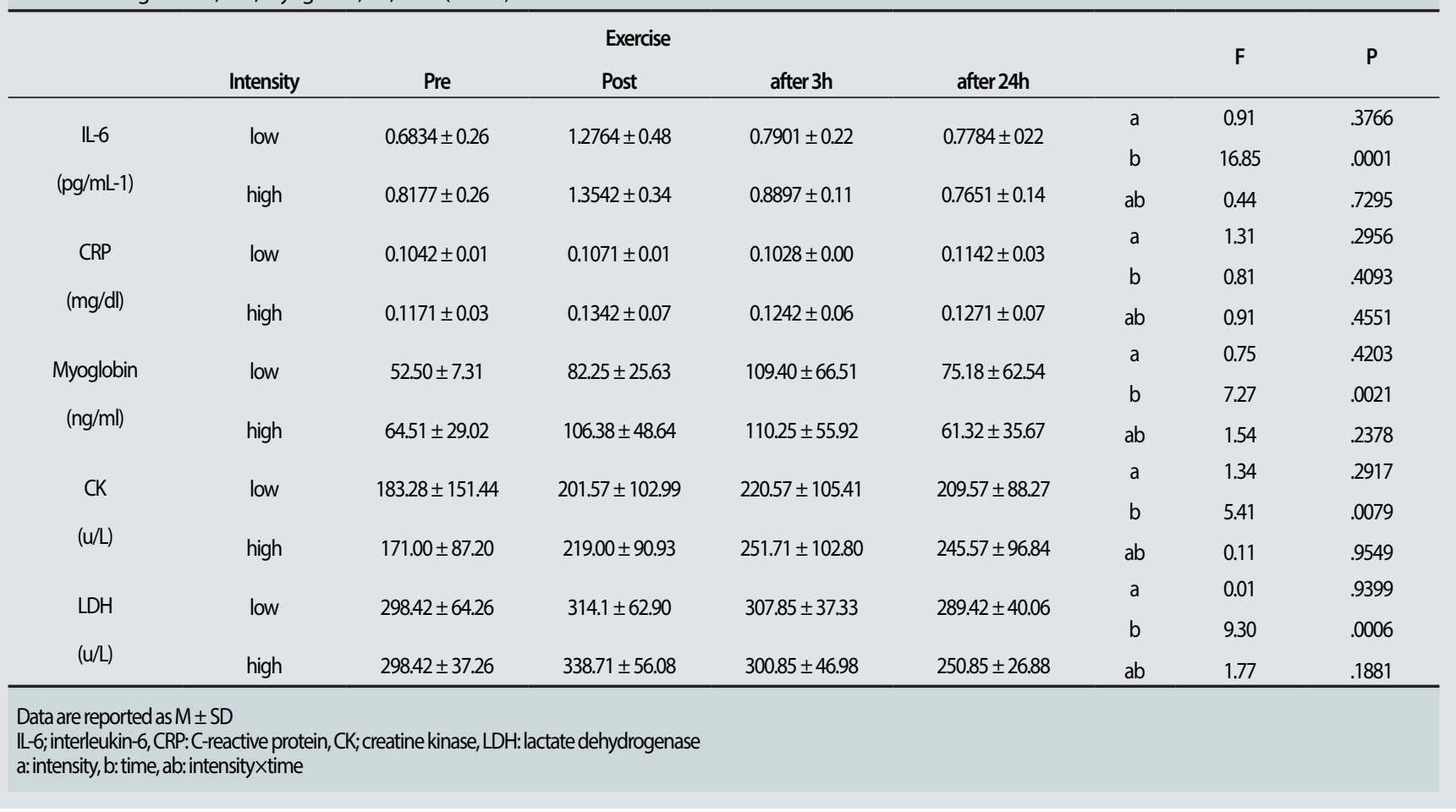

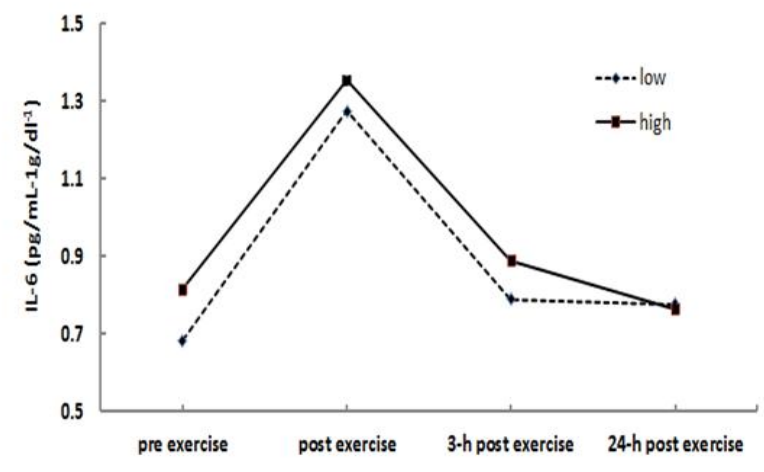

Figure 1. Change of Interleukin-6 (IL-6)

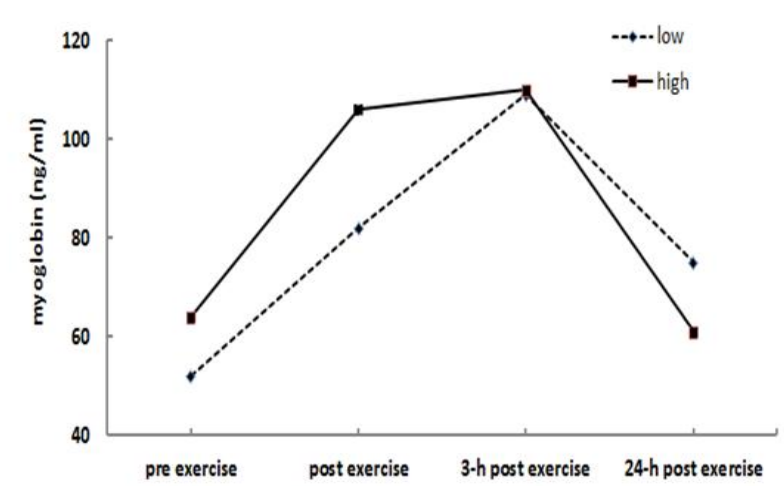

Figure 3. Change of myoglobin

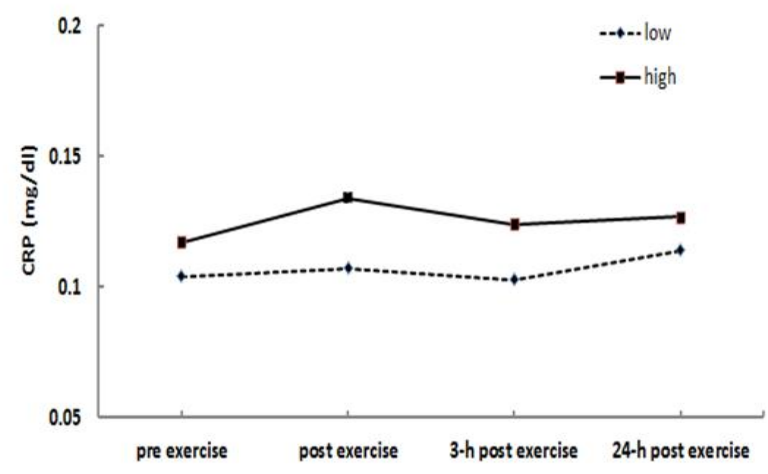

Figure 2. Change of $\mathrm{C}$-reactive protein (CRP)

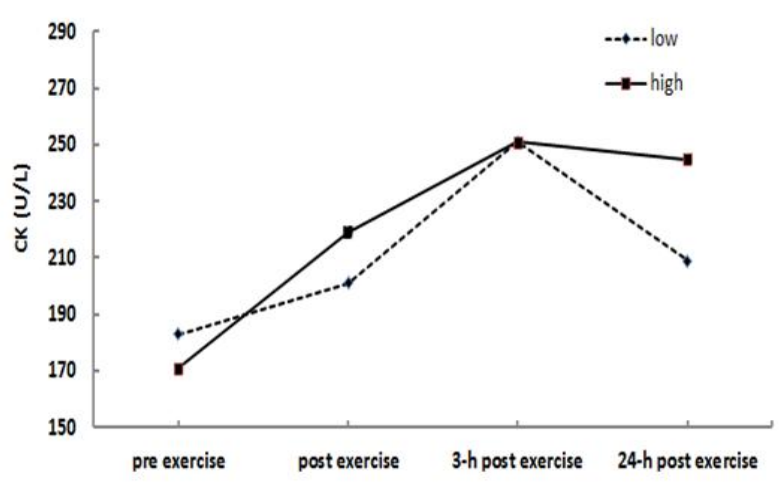

Figure 4. Change of creatine kinase (CK)

16 | The Asian Journal of Kinesiology 


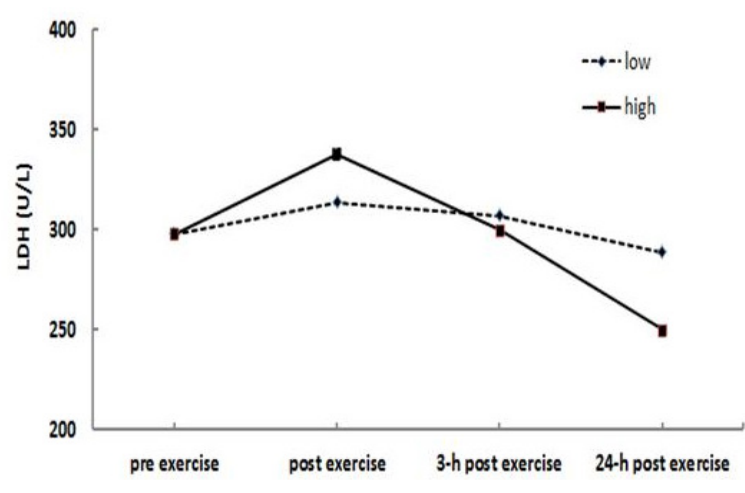

Figure 5. Change of lactate dehydrogenase (LDH)

나지 않았지만 측정시점별 유의차가 나타났다 $(\mathrm{p}<.01)$. 상 호작용효과는 나타나지 않았다<Table 3, Figure 4>.

\section{젖산탈수소효소(LDH) 변화}

$\mathrm{LDH}$ 농도 변화는 저강도와 고강도 모두 운동전에 비 해 운동 후 증가하였다. 또한 안정시에 비해 운동 후 24시 간에서는 감소하는 것으로 나타났다. 변량분석 결과 운동 강도에 따른 유의차는 나타나지 않았지만 측정시점별 유 의차가 나타났다 $(\mathrm{p}<.001)$. 상호작용효과는 나타나지 않았 다<Table 3, Figure 5>.

\section{논의}

본 연구의 목적이 일반인의 체력관리에 도움이 되고자 저항운동에 의한 근손상 결과인 염증지표의 농도와 근피 로도 중심으로 운동강도 차이에 따른 변화 추이를 시점 별 차이를 살펴보았다. 본 연구 관심의 초점인 변인 IL-6, $\mathrm{CRP}$ 및 근육 손상 피로물질인 myoglobin, $\mathrm{CK}, \mathrm{LDH}$ 등의 저항 강도의 차이에 따른 시점간 통계적 의미는 대부분 나타났으나, 강도차이 간에 시점의 상호작용은 의미가 없 는 것으로 나타났다. 본 연구가 운동 강도의 차이에 따른 효과 여부의 정보는 일반인 체력관리 활용에 도움이 될 것이다.

연구에 적용한 저항운동은 물론, 일반적인 운동 등에 서도 필연적으로 나타나는 염증반응은 일상생활의 삶 과 건강관리를 위한 방어 과정에서도 일어나는 현상이다 [14]. 그러나 바이러스 또는 미 생물인 세균 등 인체에 유해 한 감염이 지속되는 경우 과도한 염증으로 암과 같은 만
성질병 유발의 염려도 있다[12]. 염증은 주요 매개자인 염 증성 사이토카인을 분비하여 염증반응을 조절한다. 염증 성 사이토카인으로 분류되는 IL-6는 항염증 작용도 하며 근 수축에 따라 생성되어 혈중에 분비된다 $[15,29]$. 대다수 연구에서 운동 후 혈중 IL-6가 평상시보다 증가하는 것을 일반적으로 관찰되는 현상으로 여긴다. 이에 주된 영향을 미치는 것은 운동강도, 운동 지속시간 등으로 알려져 있 다. 특히 IL-6 증가의 최대 수치는 운동시 나타나며, 운동 후에도 증가상태가 일정시간대까지 유지되는 것으로 보 고되고 있다[36,38,42,48].

본 연구에서 실행한 4 5RM 고강도 운동시 운동전 IL-6 가 $0.8177 \mathrm{pg} / \mathrm{mL}-1$ 이 운동직후 $1.3542 \mathrm{pg} / \mathrm{mL}-1$ 으로 증가하 였고, 10 11RM을 반복하는 저강도 운동에서도 운동전 $0.6834 \mathrm{pg} / \mathrm{mL}-1$ 이 $1.2764 \mathrm{pg} / \mathrm{mL}-1$ 으로 통계적으로도 의미 있는 증가였으나, 적용한 강도 차이에 관계없이 운동 후 3 시간과 24시간에 IL-6의 농도는 안정시 수준으로 낮아졌 다. 운동 강도의 차이에 따른 통계적 의미도 나타나지 않 았다. 이렇게 운동 강도만 다르게 적용한 동일한 피검자 의 염증은 빠르게 회복되어 염증저항에 차이는 관찰되지 않았다. 그래서 IL-6를 기준으로 운동 직후 증가했던 염증 유발의 염려할 필요 없다고 판단된다. 이러한 현상은 이 미 4 가지 벤치프레스 강도( $1 \mathrm{RM}$ 의 $50 \%, 75 \%, 90 \%, 110 \%)$ 로 적용하여 실행했던 연구에서 저항운동 24시간 후 IL-6 농도의 차이가 없었다고 하였다[52].

한편 최근에 보고된 연구 $1-\mathrm{RM} 60 \%, 72 \%, 80 \%$ 의 저항 성 운동강도 차이와 측정시점(안정시, 운동 직후, 운동 후 $3,6,24,48$ 시간) 등 두 조건에서도 IL-6 농도의 통계적 차 이는 없었다[14]. 또한 일반연성을 대상으로 한 저항운동 강도차이 연구에서도 IL-6의 혈중 농도가 크게 다르지 않 았다[21]. 반면 본 연구에서 저항의 높고 낮음에 관계없이 운동전보다 상승한 혈중 IL-6농도가 운동직 후 시점간에 통계적으로 의미가 높은 것으로 나타났다. 이런 현상은 운동에 따른 근손상 저항 작용으로 IL6의 혈중 농도가 증 가한 것으로 판단된다.

즉 연구는 TNF- $\alpha$ 에 대한 정보를 제공할 수 없어 IL-6의 운동 직후 상승에 대한 원인을 추측에 의존할 수밖에 없 지만 선행연구를 통한 원인을 예측하면, TNF- $\alpha$ 의 증가 없 이 IL-6만 증가하는 경우, 항염증성 사이토카인의 작용으 로 보는 것도 타당성 있다는 것이다[7,36]. 그러므로 본 연 구의 운동직후 IL-6의 농도가 높은 이유를 항염증 작용에 의한 유추도 가능한 것이다. 또한 앞에 언급한 근거 외에 
다양한 염증성 질환에서 높아진다는 이유도 포함된다. 특 히 혈중 IL-6를 염증 전에 나타나는 사이토카인으로 분류 되고, 또한 스트레스 바이오마커로 저항운동 후 받은 회 복과정 평가 기준으로 활용된다[4,5].

한편 감염, 염증, 조직손상 및 운동 등에 의해 CRP는 증 가되는 것으로 잘 알려져 있다[2,33]. 간과 근육세포 등에 서 생성되는 급성반응물질 이지만 IL-6에서 생성되기도 한다. 특히 운동과 관련하여 저항운동 무경험의 일반여 성에게 적용한 고강도 저항성 운동에서 $\mathrm{CRP}$ 가 운동 후, 회복기에 높게 나타났다고 하였다[21]. 반면 최대운동 직 후와 회복시점에 CRP는 물론 IL-6의 변화도 통계적 의미 는 나타나지 않았다[10]. 이렇게 본 연구의 결과도 저항 의 강도의 차이에 따른 $\mathrm{CRP}$ 농도의 변화가 운동 전, 운동 직후 그리고 3 시간과 24 시간 뒤에도 통계적인 의미는 없 었다. 저강도 저항운동에서 $\mathrm{CRP}$ 평균농도는 운동직후에 운동 전보다 $0.0029 \mathrm{mg} / \mathrm{dl}$ 높게 나타났으나 운동종료 3시 간 후엔 운동 전보다 $0.0014 \mathrm{mg} / \mathrm{dl}$ 낮았으며, 24 시간 뒤엔 $0.0100 \mathrm{mg} / \mathrm{dl}$ 높게 나타나는 등 변화의 일정한 규칙은 없었 다. 반면에 고강도 저항운동에서는 운동 전보다 직후에 $0.0171 \mathrm{mg} / \mathrm{dl}$ 높게 나타났으나, 운동 후 3시간과 24시간 뒤 엔 $0.0071 \mathrm{mg} / \mathrm{dl}$ 과, $0.0100 \mathrm{mg} / \mathrm{dl}$ 으로 저항강도와 혈중농도 측정 시점간 차이는 보이지 않았다. 따라서 정확한 이유 를 본 연구에서 제공할 수는 없지만 대상자의 성별과 운 동경험 그리고 규칙성의 유무에서 찾아야 할 것으로 판 단된다.

이러한 판단의 근거는 저항운동의 $\mathrm{CRP}$ 농도는 운동기 간과 운동강도에 따라 달라질 수 있다[13]는 보고를 참고 하였다. 한편 $1 \mathrm{RM}$ 의 $65 \%$ 와 $80 \%$ 의 저항운동강도로 1 회성 실행 직후와 회복기에 통계적인 의미가 없었다고 하였다 [21]. 본 연구의 결과와 선행 연구 보고의 추론으로 운동 후 CRP 농도에 대한 서로 다른 견해는 운동회복 능력의 지표로 삼는 것도 한 방법일 것이다. 근활성도가 높은 근 육에 마이오글보빈 농도가 비활성 근육에서 높다는 것은 근 활성에 따른 피로물질 농도와 상당한 관련이 있다. 고 강도 운동시 마이오글로빈 농도가 증가한다는 것은 근육 세포의 손상이 높다는 것과 같은 의미로 운동강도와 밀접 한 관련을 갖는다[37]. 그러나 본 연구 결과 저항강도의 차 이에 따른 통계적 의미는 나타나지 않았으며, 독립적 시 점 간에 마이오글로빈의 농도는 운동전보다 운동 직후와 3 시간 후에 높은 것이 통계적인 의미가 나타났다. 저, 고 강도 저항운동 24 시간 후 나타난 결과는 저강도에서 안정
시 상태로 마이오글로빈 농도가 안정시 상태로 낮아졌고, 고강도 운동에서는 오히려 안정시보다 낮은 마이오글로 빈 농도가 나타났다. 높은 강도의 적은 반복횟수가 낮은 강도의 높은 빈도의 근수축보다 근 손상의 유발이 낮았 다는 추측도 가능한데, 그에 대한 근거는 근력 및 근지구 력 운동집단의 CRP 변화의 차이 연구에서 유추한 것이다 [20]. 한편 저항성 운동간 IL-6 변화와 마찬가지로 미오글 로빈도 운동 후 상승하였지만 차이가 없다고 하였다[14].

또한 운동 중 근손상으로 높아진 혈중 마이오글로빈이 헤모글로빈과 유사한 구조를 들어 근 세포의 단백질에 산 소 결합력이 강함을 들어 산소의 저장역할을 강조하기도 하였다[11]. 일반적인 저항운동이 근수축의 반복을 통하 여 근력과 지구력 등 목적에 맞는 트레이닝 과정에 발생 한 근손상으로 세포막의 투과성이 높아진다. 이러한 원인 에 의해 마이오글로빈은 물론 $\mathrm{CK}$ 와 $\mathrm{LDH}$ 등의 혈중 농도 가 높아진다는 견해다[31]. 뿐만 아니라 운동형 태, 운동강 도, 운동 지속시간 등은 근손상과 피로물질을 농도에 영 향을 주기도 하지만 근 기능의 상태를 가늠하는 지표로 유용하게 활용된다는 의견도 지속되고 있다 $[4,5,31,34,35]$.

근 조직의 손상은 혈중 $\mathrm{CK}$ 농도에 따라 그 정도의 높고 낮음이 기준이 된다. 일 반적으로 $\mathrm{CK}$ 혈중 농도의 범위(성 인 남: 55 170 u/L, 여: 30 135 u/L)는 남녀의 차이가 있으 나, 근육질의 남성은 더 높은 혈중 $\mathrm{CK}$ 농도가 나타나기도 한다. 본 연구의 대상자가 대학생으로 안정시에도 $\mathrm{CK}$ 의 범위를 벗어난 혈중 농도가 나타났다. 그 이유는 일반적 으로 $\mathrm{CK}$ 가 심근과 뇌에서도 발견되고 심근의 손상이 아 닌 경우 대부분 골격근에서 만들어지기 때문에 근육량에 따라 $\mathrm{CK}$ 의 정상 수치는 근육질의 체격이 큰 경우 정상 범 위를 벗어난다는 예를 참고하였다[3,26,39].

그리고 저항운동 강도가 높고 낮음에 관계없이 선행연 구에서 언급했던 바와 같이 운동 직후와 회복기 3 시간과 24시간 후에도 여전히 CK 혈중 농도는 높게 나타났으며, 통계적으로도 의미 있는 것으로 확인되었다. 저항강도를 높여 운동을 실행한 경우 저항강도를 낮게 빈도를 높여 운동했을 때보다 평균적으로 $\mathrm{CK}$ 혈중 농도가 증가하였 으나 강도의 차이에 따른 통계적인 의미는 나타나지 않 았다. 장시간 운동과 운동강도가 높을수록 $\mathrm{CK}$ 활성도가 증가한다 $[22,26,41,46]$ 는 통계적 의미가 본 연구와 유사한 저항성 운동강도간 $\mathrm{CK}$ 차이 없다는 보고[21]와 다른 견해 도 보이나, 일반적인 현상은 유사한 것으로 판단된다. 가 령 저항운동 $\mathrm{CK}$ 의 혈중농도가 현저하게 24 시간 동안 높 
게 유지되다가 점차 안정시 수준으로 회복된 근거[3]도 24 시간 동안 결과는 본 연구와 동일한 혈중 $\mathrm{CK}$ 농도 수준으 로 판단된다. 이렇 게 운동에 따른 근활동시 ATP 생성 반응 의 촉매 효소이기도 한 $\mathrm{CK}$ 혈중 농도가 근육 손상정도의 기준으로 활용되는 것이다[23,25,26].

$\mathrm{LDH}$ 는 $\mathrm{NAD+(nicotinamide} \mathrm{adenine} \mathrm{dinucleotide)를}$ $\mathrm{NADH}$ 로 상호 전환시켜 Lactate를 Pyruvate로 전환하는 촉 매작용을 한다. 조직이 손상되면 혈중으로 방출되는 조직 의 손상, 용혈성, 빈혈, 암, 심장마비와 같은 질병의 마커로 혈청의 종양지표로 활용된다. $\mathrm{LDH}$ 의 혈중 범위는 각 검사 기관의 차이는 있지만 성인기준 $100 ~ 190 \mathrm{u} / \mathrm{L}$ 가 대략 일반 적인 기준이다. 본 연구 대상자의 $\mathrm{LDH}$ 혈중 농도가 편차 는 있지만 $298 \mathrm{u} / \mathrm{L}$ 로 안정 시에도 정상범위 기준의 $100 \mathrm{u} / \mathrm{L}$ 이상을 벗어났다. 운동 전임에도 불구하고 이렇 게 높게 나 타난 것은, 검사 전에 활동 제한의 특별한 지침을 제시하 지 않은 이유도 있지만 근육질의 활동량 많은 젊은 대학생 이기 때문이기도 하다[50]. $\mathrm{LDH}$ 의 활성도가 운동강도와 밀접한 관련이 있다는 것은 매우 일반적인 현상으로 앞에 언급한 염증 또는 근손상 지표가 높게 유지된 것과는 다르 게 운동 24시간 후에는 안정시 상태로 회복되었다. 저항강 도를 높게 운동한 직후에 저항강도를 낮게 하였을 때 운동 직후보다 평균적으로 높은 $\mathrm{LDH}$ 의 혈중 농도를 보였으나, 통계적인 의미는 강도의 차이에 관계없는 것으로 나타났 다. 이렇게 본 연구의 결과 운동직후 시간이 지나면서 안 정시 상태로 회복이 빠르게 진행된 것도, 운동강도와 $\mathrm{LDH}$ 의 활성도를 언급한 연구 결과와 별 차이가 없는 것으로 확인되었다[25,27,47]. 또한 저항운동에서 고강도 운동 후 에 근육의 통증이 저강도 운동 후보다 더 높았지만, 역시 통계적인 차이는 본 연구와 다르지 않았다[35].

앞에 언급한 내용[6]과 같이 운동에 의해 발생된 IL-6의 농도 증가는 근손상과 관련은 있으나, 근손상의 발생과 관 계 없이 IL-6가 증가한다 $[7,15,41]$ 는 견해도 주지해야 할 것이다. 원심성 운동 후 IL-6의 분비양상은 앞에 언급한 연 구와 본 연구 결과와 크게 다르지 않았다[51].

이렇게 저항운동 뿐만 아니라 달리기 선수의 내리막길 운동 후 IL-6 농도의 변화 연구에서 안정시 상태로 회복된 반면 운동직후의 $\mathrm{CK}$ 농도는 24 시간 뒤에도 지속되었다 [38]는 사실도 본 연구와 다르지 않았다. 저항강도의 차이 가 염증반응지표와 근 손상의 피로물질 농도가 다르다는 통계적 양상이 뚜렷하지 않지만, 근력 운동시 동반되는 근 손상과 지연성 근통증의 최소화 방안은 지속적으로 찾아
야 할 것이다.

\section{결론}

앞에 언급한 바와 같이 저항강도의 차이에 따른 젊은 대학생의 혈중 염증지표와 근손상 피로물질 변화에 대한 결론은 다음과 같다.

첫째 염증지표 IL-6의 농도는 강도의 높고 낮음에 차이 는 없었으며, 시점간(운동 전, 운동 후, 운동 후 3시간, 운 동 후 24시간)엔 통계적의미가 있는 것으로 확인되었다.

둘째 $\mathrm{CRP}$ 는 저항강도의 차이는 물론 측정 시점간에도 통계적 의미의 차이는 없었다.

셋째, 근손상 피로물질인 Myoglobin, $\mathrm{CK}, \mathrm{LDH}$ 도 저항 강도의 높고 낮음에 관계없이 시점간에 통계적 차이는 확 인되었지만, 저항강도의 차이에 따른 시점간 다름은 나타 나지 않았다.

\section{Acknowledgements}

이 논문은 2017 2018년도 창원 대학교 자율연구과제 연구비 지원으로 수행된 연구결과임.

\section{Conflicts of Interest}

The authors declare no conflict of interest.

\section{References}

1. Alexander WS. Suppressors of cytokine signaling(SOCS) in the immune system. Nat Rev Immunol, 2002; 2:410416.

2. Borish LC, Steinke JW. Cytokines and chemokines. Journal of Allergy Clin Immunol. 2003; 111(2):460-475.

3. Brancaccio P, Maffulli N, Limongelli FM. Creatine kinase monitoring in sport medicine. Br Med Bull. 2007; 8182(1):209-230.

4. Brancaccio P, Maffulli N, Buonauro R, Limongelli FM. Serum enzyme monitoring in sports medicine. Clin Sports Med, 2008; 27(1):1-18.

5. Brancaccio P, Lippi G, Maffulli N. Biochemical markers of muscular damage. Clin Chem Lab Med. 2010; 48:757- 
767.

6 Bruunsgaard H, Galbo H, Halkjaer-Kristensen J, Johansen TL, MacLean DA, Pedersen BK. Exercise-induced increase in serum interleukin-6 in humans is related to muscle damage. J Physiol. 1997; 499(3):833-841.

7. Bruunsgaard H. Physical activity and modulation of systemic low-level inflammation. J Leuk Biol. 2005; 78:819-835.

8. Campos GE, Luecke TJ, Wendeln HK, et al. Muscular adaptations in response to three different resistance-training regimens: specificity of repetition maximum training zones. Eu J Appl Physiol. 2002; 88(1-2):50-60.

9. Cannon JG, St Pierre BA. Cytokines in exertion-induced skeletal muscle injury. Mol Cell Biochem. 1998; 179:159-167.

10. Cipryan L, Svagera Z, Vala R. IL-6 and CRP response to maximal exercise intervention. J Sports Med Phys Fit. 2015; 55(7-8):813-823

11. Cole RP. Myoglobin function in exercising skeletal muscle. Sci. 1982; 216:523-525.

12. Coussens LM, Werb Z. Inflammation and cancer. Nat. 2002; 420:860-867.

13. Cottel KE, Dorfman LR. Strraight CR. Delmonico MJ, Lofgen IE. The effects of diet education plus light resistance training on coronary heart disease risk factors in community dwelling older adults. J Nut Heal Aging. 2011; 15(9);762-767

14. Cornish SM, Chase JE, Bugera EM, Giesbrecht GG. Systemic IL-6 and myoglobin response to three different resistance exercise intensities in older men. J Aging Phys Act. 2018; 26(3):451-456.

15. Febbraio MA, Pedersen BK. Muscle-derived interleukin-6: mechanisms for activation and possible biological roles. FASEB J. 2002; 16:1335-1347.

16. Fischer CP. Interleukin-6 in acute exercise and training. Exe Immunol rev, 2006; 12:6-33.

17. Friden J, Sjostrom M, Ekblom B. Myofibrillar damage following intense eccentric exercise in man. Int J Sports Med. 1983: 4(3):170-176.

18. Gleeson M, Almey J, Brooks S, Cave R, Lewis A, Griffiths H. Haematological and acute-phase responses associ- ated with delayed-onset muscle soreness in humans. Eu J Appl Physiol. 1995; 71(2-3):137-142.

19. Jeon YK. The change of type of resistance exercise for muscle mass and inflammatory marker in korean women. J Kor Asso PE. Sport Gir Wo. 2014; 28(3):115-126.

20. Kim JH. Changes for muscle mass and CRP, IL- 6 by Type of Resistance Exercise. Kor J Sports Sci. 2014; 23(4):901-912.

21. Ko SK, Kwon YW. The effect of different intensity of resistance exercise on inflammatory factors and CK in sedentary women. Kor J Sports Sci. 2012; 21(4):949-960.

22. Kobayashi Y, Takeuchi T, Hosoi T, Yoshizaki H, Loeppky JA. Effect of a marathon run on serum lipoproteins, creatine kinase, and lactate dehydrogenase in recreational runners. Res Q Exe Sport, 2005; 76:450-455.

23. Koch AJ, Pereira R, Machado M. The creatine kinase response to resistance exercise. J Musculoskel Neur Interact. 2014; 14(1):68-77.

24. Kraemer WJ, Noble BJ, Clark. MJ. Physiologic responses to heavy resistance exercise with very short rest periods. Int J Sports Med. 1987; 8(4):247-252.

25. Kwon YW. The effect of acute downhill and uphill exercise on glucose lactate and CK concentration. Kor J Sports Sci. 2016; 25(6):1269-1277.

26. Kwon YW. Ko SK. The effect of different intensity with acute isocaloric exercise on inflammatory factors and CK in mentally retarded obese population. Kor J Sports Sci. 2012; 21(2):1085-1096.

27. Lee MS, Paik IY, Kwak YS, No HT, Jin HE. The effect of kinesio taping on muscle strength improvement, blood fatigue factors, muscle fatigue and damage index. J Life Sci. 2010; 20(6):870-876.

28. Lee SL, Chen KW, Chen ST, et al. Effect of passive repetitive isokinetic training on cytokines and hormonal changes. Chi J Physiol. 2011; 54(1):55-66.

29. Liburt NR, Adams AA, Betancourt A, Horohov DW, McKeever KH. Exercise-induced increases in inflammatory cytokines in muscle and blood of horses. Equine Veterinary J. 2010; 42(38):280-288.

30. Lim, KI, Suk MH, Shin YA. Effects of acute aerobic exercise on circulating adiponectin and inflammatory 
makers in obese middle-aged women. Korean J Health Pro. 2012; 12(4):203-210.

31. Lipp G, Schena F, Salvagno GL, et al. Acute variation of biochemical markers of muscle damage following a 21-km, half-marathon run. Scan J Clin Lab Inve. 2008; 15:1-6.

32. Mooren FC, Lechtermann A, Fobker M, Brandt B, Sorg C, Volker K. The response of the novel pro-inflammatory molecules S100A8/A9 to exercise. Int J Sports Med. 2006; 27(9):751-758.

33. Neubauer O, König D, Wagner KH. Recovery after an Ironman triathlon: sustained inflammatory responses and muscular stress. Eu J Appl Physiol. 2008; 104(3):417-426.

34. Noakes TD. Effect of exercise on serum enzyme activities in humans. Int J Sports Med. 1997; 4(4):245-267.

35. Nosaka K, Newton M. Is recovery from muscle damage retarded by a subsequent bout of eccentric exercise inducing larger decreases in force? J Sci Med Sport. 2002; 5(3):204-218.

36. Ostrowski K, Schjerling P, Pedersen BK. Physical activity and plasma interleukin-6 in humans effect of intensity of exercise. Eu J Appl Physiol. 2000; 83:512-515.

37. Paulsen G, Mikkelsen UR, Raastad T, Peake JM. Leucocytes, Cytokines and Satellite Cells: What role do they play in muscle damage and regeneration following eccentric exercise?. Exe Immunol Rev. 2012; 18:42-97.

38. Peake JM, Suzuki K, Hordern M, Wilson G, Nosaka K, Coombes JS. Plasma cytokine changes in relation to exercise intensity and muscle damage. Eu J Appl Physiol. 2005; 95:514-521.

39. Peterson AM, Pedersien BK. The anti-inflammatory effect of exercise. J Appl Physiol. 2005; 98(4):1154-1162.

40. Pedersen BK, Steensberg A, Schjerling, P. Muscle-derived interleukin-6: possible biological effects. J Physiol. 2001; 15, 536(2):329-337.

41. Pedersen BK, Bruunsgaard H. Possible beneficial role of exercise in modulating low-grade inflammation in the elderly. Scan J Med Sci Sports, 2003; 13:56-62.

42. Pedersen BK, Febbraio MA. Muscle as an endocrine organ: focus on muscle-derived interleukin-6. Physiol
Rev 2008; 88:1379-1406.

43. Phillips MD, Mitchell JB, Currie-Elolf LM, Yellott RC, Hubing KA. Influence of commonly employed resistance exercise protocols on circulating IL-6 and indices of insulin sensitivity. J Streng Cond Res. 2010; 24(4):1091-101.

44. Sesso HD, Wang, L., Buring JE, Ridker PM, Gaziano JM. Comparison of interluukin-6 and C-reactive protein for the risk of developing hypertension in women. Hyper. 2007; 49(2):304-310.

45. Shephard RJ, Shek PN. Immune response to inflammation and trauma: a physical training model. Can J physiol pharmacol. 1999; 76:469-472.

46. Skenderi KP, Kavouras SA, Anastasiou CA, Yiannakouris, N, Matalas AL. Exertional rhabdomyolysis during a 246-km continuous running race. Med Sci Sports Exe. 2006; 38:1054-1057.

47. Stansible D, Aston JP, Dallimore NS, Williams HM, Wills N. Effect of exercise on plasma pyruvate kinase and creatine kinase activity. Clinica Chimica Acta, 1983; 132(2):127-132.

48. Suzuki K, Nakaji S, Yamada M, et al. Impact of a competitive marathon race on systemic cytokine and neutrophil responses. Med Sci Sports Exe. 2003; 35(2):348355.

49. Tartibian B, Azadpoor N, Abbasi A. Effects of two different type of treadmill running on human blood luekocyte populations and inflammatorty indices in young untrained men. J Sports Med Physical Fit. 2009; 49(2):214-223.

50. Thomas SJ, Cooney TE, Thomas DJ. Comparison of exertional indices following moderate training in collegiate athletes. J sports Med physical Fit. 2000; 40(2):156-161.

51. Toft AD, Jensen LB, Bruunsgaard H, et al. Cytokine response to eccentric exercise in young and elderly humans. Ame J Physiol. 2002; 283:289-295.

52. Uchida MC, Crewther BT, Ugrinowitsch C, Bacurau RF, Moriscot AS, Aoki MS. Hormonal responses to different resistance exercise schemes of similar total volume. J Streng Cond Res. 2009; 23(7):2003-2008. 